розробляються варіативні проекти та моделі загальнопедагогічної підготовки вчителя (С. Ананьїн, Ф. Зеленогорський, В. Зеньківський, О. Музиченко, П. Тихомиров), зміст якої вибудовувався за наступними напрямами: філософсько-педагогічним (предмети педагогічного циклу читалися викладачами філософії, розглядалися як іiі складові); релігійно-педагогічним (предмети педагогічного спрямування затверджувалися Святим Синодом, знаходилися під впливом «основного» і «морального» богослов'я); психологопедагогічним (педагогічні дисципліни викладалися психологами, у тісному зв'язку й на основі психологічних знань); прагматично-педагогічним (у загальнопедагогічній підготовці вчителя переважав практичний компонент); педолого-експериментальним (акценти переносилися на особистість дитини, дослідно-експериментальне іiі вивчення); соціально зорієнтованим (у викладанні загальнопедагогічних дисциплін посилювався виховний аспект, зміцнювався зв'язок із соціумом); професійно зорієнтованим (загальнопедагогічна підготовка виокремилася в самостійний, стабільний напрям формування особистості вчителя). Перспективу подальшого дослідження становить організація науково-педагогічної освіти випускників магістратури.

\title{
Література
}

1. Важинський І. П. Становлення і розвиток педагогічної освіти в центральній та східній Україні (1802-1866 рр. ) / І. П. Важинський : Автореф. дис. ... канд. пед. наук : 13.00.01/ Полтавський державний педагогічний університет ім. В. Г. Короленка. - К., 2002. - 17 с. 2. Дем'яненко Н. М. Загальнопедагогічна підготовка на Київських вищих жіночих курсах (18781920 рр.) / Н.М. Дем'яненко // Педагогіка і психологія. - 1997. - № 4. - С. 211-216. 3. Коржов Д. Ю. Розвиток системи вищої освіти в Україні (кінець XIX-початок XX ст.) : навч. посіб / Д. Ю. Коржов. - Вінниця : ПП «Центр генеалогії і біографії», 1996. - 16 с. 4. Микитюк О. М. Університет як центр науково-дослідної роботи / О. М. Микитюк // Педагогіка та психологія. 2001. - № 18 ( 2 ). - С. 5-12. 5. Очерки истории школы и педагогической мысли народов СССР. Конец XIX - начало XX в. / Под ред. Э. Д. Днепрова, С. Ф. Егорова, Ф. Г. Паначина, Б. К. Тебиева. - М. : Педагогика, $1991-448$ с.

УДК 37.(091)

О. А. Устименко-Косорич,

докторант,

Луганський наиіональний університет імені Тараса Шевченка

\section{МУЗИЧНО-ПЕДАГОГІЧНИЙ ПРОФІЛЬ С. МОКРАНЬЦА В КОНТЕКСТІ РОЗВИТКУ МУЗИЧНОЇ ОСВІТИ СЕРБIї}

Устименко-Косоріч О. А. Музично-педагогічний профіль С. Мокраньца в контексті розвитку музичної освіти Сербії.

У статті визначено музично-педагогічний контекст творчості С. Мокраньца у процесі становлення сербської музичної освіти. Зазначені концептуальні музично-педагогічні ідеї діяча визначили шлях подальшого розвитку власної музичної школи Сербії. Розглянуто музично-освітні тенденції становлення музично-педагогічної школи Сербії в певній історико-культурній послідовності.

Ключові слова: музична освіта, музична школа, педагогічні ідеї, викладач, діяч, композитор, диригент, історико-культурна періодизація.

Устименко-Косорич Е. А. Музыкально-педагогический профиль С. Мокраньца в контексте развития музыкального образования Сербии.

В статье определен музыкально-педагогический контекст творчества С. Мокраньца в процессе становления сербской музыкального образования. Указанные концептуальные музыкальнопедагогические идеи деятеля определили путь дальнейшего развития музыкальной школы Сербии. Рассмотрены музыкально-образовательные тенденции становления музыкально-педагогической школы Сербии в определенной историко-культурной последовательности.

Ключевые слова: образование, музыкальная школа, педагогические идеи, преподаватель, 
деятель, композитор, дирижер, историко-культурная периодизация.

Ustymenko-Kosorich O. A Musical and Pedagogical profile S. Mokranyat's in the context of music education Serbia.

The article outlines the musical and pedagogical context creativity S. Mokranyat's in the process of Serbian music education. Educational, conductor, composer activity S. Mokranyat's had a significant influence on the development of the national Serbian music. These conceptual musical and pedagogical ideas figure defined path forward his own music school of Serbia. Considered musically Яeducational tendencies of the music-school teacher Serbia in a particular historical and cultural order.

Key words: music education, music school, teaching ideas, teacher, activist, composer, conductor, historical and cultural periods.

Стрімкий розвиток музичної освіти Сербії та виконавських шкіл, прогресивні тенденції музично-педагогічного виховання складає культурно-національний феномен локально зазначеної країни. Сучасні дослідники приділяють значну увагу розвитку музичнопедагогічної думки Сербії другої половини XX століття, вивченню діяльності діячів та композиторів Сербії, соціології сербської музики, музично-педагогічної освіти Сербії у освітньому Європейському просторі. Їхні роботи збагатили знання відповідним фактологічним матеріалом, теоретичними висновками, але до визначень певних періодів історичного розвитку музичної педагогіки й освіти Сербії вони не вдавались. Музичнопедагогічна, просвітницька діяльність С. Мокраньца залишилась за межами спеціального дослідження. У статті здійснено спробу визначити та узагальнити стратегічні музичнопедагогічні ідеї С. Мокраньца в історико-культурній послідовності розвитку національної музичної школи Сербії, у чому й полягає іiї актуальність.

Вивчення музично-педагогічної та історичної літератури дозволив констатувати, що до визначення періодизації розвитку музичної освіти зверталися ряд дослідників. Автори розкривали еволюцію сербської музичної школи з різних позицій: відповідність основним канонам загальнопедагогічної думки, музичної педагогіки або в контексті європейського освітнього простору. 3-поміж них: 3.-М, Васілєвіч, Б. Йованчіч, Т. Богавац, С. ДжурічКлайн, П. Майсторовіч, К. Манойловіч. У висновках багатьох авторів спостерігається узагальненість поглядів, упровадження схожих наукових підходів, що $є$ результатом вивчення однакових історичних подій. Розкриваючи розвиток сербської баянноакордеонної школи, зазначено приклади періодизацій, наведених науковцями, які висловлюють власне бачення історії розвитку музичної освіти.

Mema cmammi - дослідити історико-культурну періодизацію становлення музичної школи Сербії та визначити роль С. Мокраньца у процесі розвитку національної музичної освіти.

Активізація досліджень історії музичної освіти Сербії відбувається у другій половині XX століття. Переважно це стосується організації та структури музичної освіти у різні історичні періоди, але зміст сучасної музичної освіти залишається поза межами наукових досліджень.

3.-М. Васілєвіч дослідила історико-соціальні події кінця XIX - початку XX століть, що безпосередньо впливали на розвиток науково-педагогічної думки, школи, музичної освіти охарактеризувала цей період, громадсько-політичну та педагогічну діяльність визначних осіб, які сприяли розвитку сербської національної школи.

С. Джуріч-Клайн підкреслює, що у другій половині XIX століття було засновано Урядові школи - музична школа (21. 12. 1863, № 3956 зап. Мнс. ФІ - п 142/1864) та школа співу (30.12. 1963, № 4002, зап. Мнс. ФI - п 142/1864) [4, с. 23]. Ініціаторами та засновниками цих шкіл були М. Міловук та К. Станковіч, які й були авторами першого Закону про музичну школу. Структура урядових шкіл майже не відрізнялася: передбачалось трьохрічне навчання у музичній школі на умовах зарахування на перший рік навчання дітей віком до 12 років та двохрічне у школі співу, рік вступу залежав від специфіки вокальних та тембральних можливостей учня. Зазначимо, що підготовка 
фахівців-співаків була зосереджена на вихованні хормейстерів православних храмів та регентів, виховання солістів до планів школи не входило. На думку С. Джуріч-Клайн, засновані Урядові школи не внесли суттєвих змін у стан шкільної справи, організація та структура цих музичних закладів характеризувалась «утопічністю ідей для сербського суспільства того часу» $[4$, с. 47$]$.

У ті ж роки при Белградському співочому товаристві починає працювати музична школа, яка спеціалізувалась на двох напрямках - скрипка та віолончель. Домінуюча позиція роботи цієї школи - виховання висококваліфікованого виконавця стала міцним професійним грунтом для подальшого розвитку інструментальної освіти в Сербії.

За три роки школа Белградського співочого товариства перейменована у Белградську гімназію, яка випустила плеяду майбутніх виконавців та артистів Національного театру.

Збільшення вчителів музики фахівцями інших країн переважно з Чехії гальмувало процес розвитку теоретичної та методологічної бази в музично-професійному сенсі, оскільки іноземні фахівці не брали участі у розбудові шкільної освіти та складанні навчальних програм. Наказ Міністра освіти Й. С. Поповіча про обов'язкове написання викладачами шкіл та гімназій інструктивної літератури торкався майже усіх освітніх галузей, окрім музичної [2, с. 32]. Музично-педагогічна школа грунтувалась на принципах загальної освіти та педагогіки, тому поява будь-якої розробки за фахом мала значний вплив на організацію навчального процесу в музичних закладах Сербії. Перші спроби написання музичної літератури торкалися викладання співу в загальних школах (збірники «Гудало», «Српска независност» - 1886 р.).

Аналіз музично-освітньої ситуації періоду кінця XIX початку XX століття здійснено Д. Блажеком та Р. Толінгером. Автори розглядають передумови та наслідки становлення музичної педагогіки, зосереджують увагу на недоліках та причинах відсталого розвитку музичної культури у певних слов'янських народів. Р. Толінгер у своїх дослідженнях надав вчителям та школам знакову функцію у вихованні дітей та підмітив, що робота викладачів має вирішальне значення у музичному вихованні усього народу [3, с. 36].

Діяльність С. Мокраньца - викладача музично-теоретичних дисциплін дістало критики у працях Р. Пейовіч, Д. Янковіча, В. Іліч, які уважають, що методи викладання музичних дисциплін «не мають нічого спільного 3 національно-релігійним атрибутом сербського суспільства» [2, с. 65]. Але дослідниками не визначено жодних музично-педагогічних ідей С. Мокраньца, які не відповідають рівню його педагогічної компетентності. Критичний аналіз сербського культурно-музичного діяча, композитора та викладача, на нашу думку, $\epsilon$ недостатньо обгрунтованим, оскільки педагогічний аспект та галузь його діяльності в роботах науковців висвітлено саме епізодично, що применшує його значення в історії сербської музичної педагогіки.

С. Мокраняц тривалий час викладав нотну грамоту в гімназії, але мав недостатню практику роботи 3 учнями в загальних школах. Відсутність професійних музикантів гальмувало процес уведення музичних дисциплін в навчальний процес освітніх установ. Тільки педагогічні професійні школи мали музичні дисципліни (нотний спів та гру на скрипці). Головним завданням гімназій - навчити основам музичної теорії та співу, що уможливлювало подальше професійне удосконалення в інших музичних закладах інших країн. Завдяки прийнятим Законам про формування «музичних шкіл» та «шкіл співу» відбувалось збільшення музичних дисциплін у загальних школах. У Законі про школу зазначено, що сербська музична школа - «професійно-педагогічна установа, яка виховує викладачів музики та діячів, яка спирається на національних традиціях та теоретичному, практичному досвіду провідних музично-освітніх закладів інших країн у процесі виховання диригентів, вчителів музики, співаків та інструменталістів (1889 рік)» [3, с. 43].

31899 р. до 1914 років С. Мокраняц викладав загальні музично-теоретичні дисципліни (сольфеджіо, теорія, спів у хорі), сформував власну школу, але його педагогічна діяльність у історії сербської музично-педагогічної думки майже не висвітлено. 
У 1901 році С. Мокраняц видав посібник «Збирка песама у један и два гласа, за дечја забавишта, основне и ниже среднье школе», у якій визначив провідні напрями удосконалення музичного виховання у школах, підкреслив необхідність суттєвих змін у музичній педагогіці засобом упровадження німецького досвіду початкової освіти у систему національної шкільної справи. Збірка складається 3 двох розділів: перший містить загальну концепцію розвитку сербської музичної педагогіки, теоретичне обгрунтування недоліків музичної освіти та методичні вказівки до іiі удосконалення; другий - складається з нотних прикладів, які, на думку автора, є найбільш змістовими та різноплановими.

Музично-педагогічна концепція С. Мокраньца складається з таких позицій: створення навчально-методичного посібника 3 репертуаром, що містить елементи сербського фольклору; головним чинником у формуванні музичних здібностей учнів - єдність мелодії та віршу з опорою на народну атрибутику; єдність метро-ритмічної пульсації мелодії та акценту вірша як фактор розвитку музичних здібностей учнів та пам'яті; різножанровість навчального репертуару для всебічного розвитку музичних здібностей учнів; узгодженість мелодії, віршу та гармонії як складник формування гомофонногармонійного слуху в учнів; відповідність ритмічної та метричної організації як атрибут сербської народної музики. На думку автора, аритмічність у побудові музичних творів та порушення у метричної пульсації є неприпустимим у формуванні музичних здібностей учнів. Теоретик, викладач, композитор, методист та фахівець музично-теоретичної справи вказував на недоліки в композиторській техніці творів, які були створені дилетантамиаматорами.

До початку XX століття значний вплив на розвиток музичної шкільної справи мала церква, оскільки програма музичних дисциплін складалася з творів духовної музики («Слава тебје Господи», «Велико Амин», «Велико Господи помилуј»). Релігійний контекст викладання музики в загальних школах змінено тільки в період 1917-1945 років, коли в навчальну програму активно впроваджується народно-популярний репертуар.

С. Джуріч-Клайн у дослідженні історії розвитку музичної освіти Сербії спирається на фактологічні дані розвитку Музичної школи Белграда та визначає три періоду: перший 1899 - 1914 роки; другий - 1914 - 1923 роки; третій - 1923 - 1948 роки. Дослідниця визначила видатних викладачів тих часів (К. Бабіч, Й. Станковіч, Б. Драгутіновіч, Станіслав та Мирослава Бінічкі, І. Мілутіновіч), в історичній послідовності названі прізвища випускників, які гідно представляють навчальний заклад на світовій арені. Навчальний план складалися на основі освітнього досвіду інших країн, що були адаптовані С. Мокраньцем у системі початкової Музичної школи Белграда, які визначили трансформацію у системі музичної освіти: від виховання спеціалістів широкого профілю диригентів, вчителів музики, співаків та інструменталістів до спеціалізованої форми підготовки музикантів, яка сприяла подальшому вдосконаленню майстерності на інших музично-освітніх рівнях. Змінено також напрями підготовки: від вокально-хорової до інструментально-виконавської з метою підготовки професійних концертних виконавців, хормейстерів, артистів оркестру, педагогів та діячів мистецтва. Тенденція до розвитку академічного музично-освіти визначились у репертуарній політиці навчальновиконавських програм, які спирались на твори видатних композиторів епохи Бароко, Класицизму та Романтизму.

Музична школа Белграда стала першою навчальною установою підготовці музикантів за фахом, яких не вистачало в освітніх закладах країни, що з часом зменшило кількість іноземних викладачів. Підвищення професійного рівня засобами виконавської діяльності, домінування інструментальної спрямованості мали суттєвий вплив на розвиток музичної культури Сербії, яка відзначилась збільшенням музично-педагогічних кадрів; випускники школи удосконалювали виконавську майстерність у вищих навчальних закладах інших країн; формувались музичні інструментальні та вокальні колективи. 
Педагогічно-творчий профіль Музичної школи Белграда визначив широкий спектр музичної освіти - оволодіння засобами вокально-інструментального виконавства, розуміння естетичного змісту музично-креативної діяльності та визнання народної музичної традиції. Педагогічна професійна компетентність викладачів школи полягала у всебічній обізнаності усіх складників музично-творчої діяльності (теоретичні знання, володіння декількома інструментами, диригентська майстерність, спів тощо).

3.-М. Васілєвіч зазначає, що перша сербська Музична школа досягла значних результатів завдяки творчій діяльності та педагогічним ідеям С. Мокраньца, заклала міцне підгрунтя для подальшого розвитку академічної музичної освіти, але за роки його керівництва так і не здобула статусу класичного музично-освітнього закладу [2, с. 23].

У 1914-1923 роках відбуваються значні перебудови у викладацькому складі, на зміну педагогічним ідеям С. Мокраньца заступили молоді викладачі (І. Мілутіновіч - сольний спів, М. Мілоєвіч - теоретичні основи, Й. Зорко - сольфеджіо), які привнесли зміни до навчальних програм: зменшена кількість випускних екзаменів, пожвавлення музичного виховання спрощеними формами викладання дисциплін. На думку 3.-М. Васілєвіч, удосконалення музично-професійної майстерності формою «факультативного» викладання теоретичних дисциплін мало руйнівний характер.

Другий етап розвитку музичної освіти характеризується негативними тенденціями: Перша світова війна, спирання на спрощені системи у формуванні музичної освіти на основі естетично-креативних позицій нового покоління викладачів, відмова від строгих канонів педагогічної концепції С. Мокраньца мали незворотні наслідки, які в історії сербської музичної освіти визначено «періодом застою» [2, с. 45].

Третій період (1914-1948) - відбувається поступова децентралізація західної моделі виховання у систему сербської музичної освіти, заснованої на німецькому музичнопедагогічному досвіді, що свідчить про розрив із національним музикоцентризмом та педагогічними ідеями С. Мокраньца. На етапі Сербської державності було закладено підвалини для синкретичного музичного виховання молоді, його творчого розвитку на національній музичних традиціях як складника світового надбання. У 1942 році в Белграді відкрито приватну школу «Звук» за напрямком фортепіано, скрипка та баян-акордеон, яка функціонувала до 1945 року. Випускницею цієї школи стала В. Вуковіч-Терзіч, яка стала ідейним ініціатором подальшого розвитку баянно-акордеонної освіти в Сербії.

Перша половина XX століття відзначається інтенсивними пошуками у галузі методики викладання музики в Сербії і в цьому сенсі важливим внеском у розвиток музичнопедагогічної та освітньої справи є роботи швейцарського музичного критика та методиста Ж. Далкроза, на якого посилався Й. Мірковіч у своїх дослідженнях, підкреслюючи значущість естетичного виховання молоді засобами музики. Теоретично-методичні засади Й. Мірковіча визначили наступний шлях у розвитку музичної педагогіки та шкільної справи.

У середині XX століття відбувається подальша професіоналізація музичної освіти, яка сприяла з одного боку, - досягненням виконавців-музикантів на світовій арені, а з іншого - занепаду музично-естетичного виховання в музичних школах і підготовки спеціалістів за фахом.

Т. Богавац, розглядаючи освітню ситуацію періоду Другою світовою зазначає, що у цей складний час для сербської культури дедалі зростав рівень професіоналізму в системі музичної освіти завдяки обміну досвідом між музично-виконавськими школами у роки евакуації. В сербських навчальних закладах працювали талановиті музиканти: П. Коньовіч, С. Христіч, М. Мілоєвіч, Й, Словенський, Д. Чоліч, М. Рістіч, Л. Маріч та ін. Були спроби подальшого формування і розвитку сербського національного музики для різних рівнів навчання [2, с. 50$]$.

У 1960 роках з метою підвищення рівня музичного виховання молоді в середніх школах відкриваються музично-педагогічні курси, де використовуються новітні методичні заходи 3 використанням досягнень у галузі психології, філософії, педагогіки, 
музикознавства, які сприяють відродженню концепції синкретичної підготовки висококваліфікованих музикантів.

Період кінець XX початок XXI століття характеризується становленням та розв'язанням національних музично-освітніх питань на новому світоглядному рівні, який базується на досвіді музичного виховання особистості різних провідних національних музичних шкіл. Відроджуються ідеї музично-естетичного розвитку молоді у загальноосвітніх школах, який спирається на комплексний підхід «слухання, спів i виконання» та удосконалюється у вищих навчальних закладах, музично-педагогічних факультетах (м. Вранє, м. Белград, м. Крагуєвац, м. Новий Сад).

Узагальнюючи етапи розвитку музичної освіти на різних періодах, можна зробити такі висновки. У процесі вивчення шляхів розвитку музичної освіти спостерігаються часи інтенсивного розвитку сербської музичної школи та періоди «застою» або занепаду. У контексті узагальнення періодизації розвитку сербської музичної школи та тенденцій національно-освітнього процесу визначено роль С. Мокраньца у побудові музичнопедагогічного концепту. Висвітлено поступовість використання наукових концепцій у вихованні творчої особистості, спрямованих на побудування системи національного музично-творчого виховання молоді та підготовки музично-педагогічних кадрів для реалізації цієї місії у сучасному культурному просторі Сербії.

Підсумовуючи, зазначимо, що в історичному аналізі висвітлених дослідниками періодів закладена суперечність в оцінюванні діяльності діячів, музикантів та викладачів різних музичних спеціальностей. 3'ясування цих питань - доцільні напрямки для подальших розвідок у галузі музичної педагогіки та освіти Сербії.

\section{Література}

1. Егорова В. В мире современной сербской музыки / В. В. Егорова. - М. : Композитор, 1999. 184 с. 2. Боговац Т. Школство у Србији на путу до реформе / Т. Боговац. - Београд, Стручна книга,1980. - 358 с. 3. Василевич 3.-М. Рат за српску музичку писменост / 3.-М. Василевич. Просвета. - Београд, Мидим принт, 2000. - 292 с. 3. Джурич-Клајн С. Библиография о Стефану Мокраньцу / С. Джурич-Клајн. - Београд, САНУ,1971. -253 с. 4. Милојувич М. Уметничка личност Стефана Мокраньца / М. Милојувич. - Београд, САНУ, 1926. - С. 91-113.

УДК:2-75(09)(477) «16/17»

B. В. Фазан,

доктор теологічних наук, кандидат педагогічних наук, доиент,

Полтавський національний педагогічний університет імені В. Г. Короленка

\section{ПРОСВІТНИЦЬКА ДІЯЛЬНІСТЬ ЛАВР В УКРАЇНI (КІНЕЦЬ XVII- XVIII СТ.)}

Фазан В. В. Просвітницька діяльність Лавр в Україні (кінець XVII- XVIII ст.).

У статті розглянуто та охарактеризовано передумови, які сприяли становленню просвітницької діяльності Лавр в Україні. Проаналізовано позитивний вплив Лавр на освіту суспільства.

Ключові слова: просвітництво, Лаври, богослів'я, духовність, релігійна освіта.

Фазан В. В. Просветительская деятельность Лавр в Украине (конец XVII- XVIII ст.)

Рассмотрены и охарактеризованы предпосылки которые способствовали становлению просветительской деятельности Лавр в Украине. Проанализировано позитивное влияние Лавр на образование общества.

Ключевые слова: просветительство, Лавры, богословие, духовность, религиозное образование.

Fazan V. V. Elucidative to activity of Large monastery in Ukraine (XVII- XVIII in.)

Pre-conditions are considered and described which was instrumental in becoming of elucidative activity Large monasteries in Ukraini. Positive influence of Large monasteries is analysed on formation of society.

Key words: education, Large monasteries, divinity, spirituality, religious education. 